Middle East Journal of Agriculture Research

EISSN: 2706-7955 ISSN: 2077-4605

DOI: 10.36632/mejar/2020.9.4.74
Volume : 09 | Issue : 04| Oct.-Dec. | 2020

Pages:959-969

\title{
Effect of exposure times of gaseous ozone on quality of strawberry fruits during cold storage
}

${ }^{1}$ Samia S. Elkeleny, ${ }^{2}$ Sheren A. Atala and ${ }^{3}$ Diaa O. El-Ansary

${ }^{I}$ Department of Postharvest and Handling of Vegetable Crops, Horticulture Research Institute, Agricultural Research Center, Sbaheya, Alexandria, Egypt.

${ }^{2}$ Department of Postharvest and Handling of Vegetable Crops, Horticulture Research Institute, Agricultural Research Center, Giza, Egypt.

${ }^{3}$ Department of Pomology, Faculty of Agriculture (El-Shatby), University of Alexandria, Egypt.

Received: 30 Oct. 2020 / Accepted 15 Dec. 2020 / Publication date: 25 Dec. 2020

\begin{abstract}
Strawberry fruits (Fragaria $\times$ ananassa) of the cultivar "Festival" were harvested at $75 \%$ maturity on $5^{\text {th }}$ and $9^{\text {th }}$ February in 2017 and 2018 seasons, respectively from private farm in Bader Center, Behera Governorate, Egypt and transported to the postharvest Center, Faculty of Agriculture, Alexandria University, to evaluate the effect of exposure times $(10,20,30,40$ and $50 \mathrm{~min}$.) of ozone gas on quality attributes of strawberry fruits during storage at $0^{\circ} \mathrm{C}$ for 21 days. Results showed that all ozone treatments of strawberry fruits reduced weight loss and did not show any decay until the end of storage period. Strawberry fruits which exposed to ozone gas for $30 \mathrm{~min}$. was the most effective treatment in maintaining fruit quality, it would reduce weight loss percentage and resulted in fruits with no decay and maintained fruit firmness, TSS, ascorbic acid content, anthocyanins content and total sugars and also gave fruits with good appearance after 21 days of storage at $0^{\circ} \mathrm{C}$ and $95 \% \mathrm{RH}$ as compared with the other treatments and untreated control.
\end{abstract}

Keywords: strawberry, ozone, anthocyanins, decay, appearance, storability.

\section{Introduction}

Strawberries (Fragaria $\times$ ananassa) have high nutritional quality characterized by unique and highly desirable taste and flavor, relevant sources of bioactive compounds due to high levels of vitamin $\mathrm{C}$ and $\mathrm{E}$, carotene and phenolic compounds such as anthocyanins, substances related to health benefits (Kuchi and Sharavani, 2019). On the other hand, many researchers found that strawberries have a very short shelf life due to their sensitivity to fungal attack and excessive texture softening caused by the natural ripening process. Also, it was found this is because strawberry is very susceptible to mechanical injury, water loss, decay and physiological deterioration after harvesting; this reduces its economic value. Moreover, quality attributes of fruits also deteriorates with time, thus rendering unsafe product for consumers (Han et al., 2005, Ali et al., 2011 and Stolfa et al., 2014). Coelho et al. (2014) indicated that the strawberry is a small crop of great important in all around the world but has a high susceptibility to a large variety of phytopathogenic organisms, promoting considerable post-harvest losses. Thus, sanitizing step becomes important process to maintain fruit quality and proper fruit storage is an effective way to maintain the quality of fruits after harvest (Stolfa et al., 2014). Hence the idea of using ozone as a postharvest treatment of strawberry fruits came up (Perez et al., 1999). Ozone is a natural gas on earth. Naturally, it is produced by reaction of oxygen with ultraviolet light from sunlight or lightning (Suslow, 2004). The use of ozone increased significantly after it was deemed safe in the USA and approved as a recognized food additive by the US-FDA (U.S. FDA 1999). Guzel-Seydim et al. (2004) showed that ozone is one of the potential alternatives that can be used as a sanitizing agent for postharvest application. Compared to other gases that are used in postharvest treatment, ozone is generally easy to detect by distinct smell. Previously, ozone is well known for their highly antimicrobial activity due to its high oxidative properties that can kill most microbes. Palou et al. (2007) reported that ozone is very oxidative at high concentration and it is also easily decompose back to oxygen in a very short time leaving only oxygen and no other harmful by product. Karaca and Velioglu (2007) and Souza et al. (2018) found that ozone $\left(\mathrm{O}_{3}\right)$ is a powerful oxidant agent and concluded that ozone as gas can be

Corresponding Author: Samia S. Elkeleny, Department of Postharvest and Handling of Vegetable Crops, Horticulture Research Institute, Agricultural Research Center, Sbaheya, Alexandria, Egypt. 
used in vegetables without harming the quality. Zhang et al. (2011) indicated that the treatment of 4 ppm ozone could hindered the decrease of ascorbic acid, weight loss and the treatment delayed the senescence of strawberry, despite of significant respiration rate. They concluded that the ozone could be good treatment maintaining postharvest quality of strawberry and provide a longer storage life. Thaer et al. (2013) showed that ozone treatment plays a control effect on microorganism contamination and increases shelf life of strawberry. Coelho et al. (2014) illustrated that ozonated strawberry fruits at concentrations $0.2,0.5$ and $1.0 \mathrm{mg} / \mathrm{L}$ for 5 minutes showed superior performance in reducing postharvest phytopathogens, whereas the concentration of $0.5 \mathrm{mg} / \mathrm{L}$ for 5 minutes delayed and decreased the disease incidence in fruits. Morais et al. (2015) concluded that the application of ozone gas to maintain the physic-chemical and microbiological characteristics is efficient for storage of strawberry fruits for up to 10 days.

The present study was carried out to investigate the effect of exposure times of gaseous $\mathrm{O}_{3}$ on the quality attributes of strawberry fruits during cold storage and to determine the optimum exposure time for the $\mathrm{O}_{3}$ gas to maintain quality and storability of strawberry fruits.

\section{Materials and Methods}

Strawberry fruits (Fragaria $\times$ ananassa) of the cultivar "Festival" were harvested at $75 \%$ maturity on $5^{\text {th }}$ and $9^{\text {th }}$ February in 2017 and 2018 seasons, respectively from private farm in Bader Center Behera Governorate, Egypt and transported to the Postharvest Center, Faculty of Agriculture, Alexandria University, Egypt.

Ozone gas (100 ppm at air flow rate of $2.5 \mathrm{~L} / \mathrm{min}$ with ozone output of $300 \mathrm{mg} / \mathrm{hr}$ ) was used in this study and produced by a laboratory corona discharge ozone generator (Xetin Ozone Air \&Water purifier, Model XT 301, Xetin Co. Ltd,Taiwan). The ozone generator was warmed up for 15 min before the experiment was conducted. (Osman, 2015).The ozonation process was carried out in closed foam box, $60 \times 40 \times 30 \mathrm{~cm}^{3}$.

Fruits were packed in panetts and each panett contain $250 \mathrm{~g}$ as one replicate and divided into six following groups:-

1. Control (without treatment).

2. Fruits were exposed to $\mathrm{O}_{3}$ gas for $10 \mathrm{~min}$.

3. Fruits were exposed to $\mathrm{O}_{3}$ gas for $20 \mathrm{~min}$.

4. Fruits were exposed to $\mathrm{O}_{3}$ gas for $30 \mathrm{~min}$.

5. Fruits were exposed to $\mathrm{O}_{3}$ gas for $40 \mathrm{~min}$.

6. Fruits were exposed to $\mathrm{O}_{3}$ gas for $50 \mathrm{~min}$.

After ozonation, panetts were packed in polypropylene bags $30 \mu \mathrm{m}$ thickness. The samples were arranged in complete randomized design with three replicates, each treatment consist of 21 panetts and stored at $0^{\circ} \mathrm{C}$ and $95 \% \mathrm{RH}$ for 21 days. Three replicates from each treatment were taken at random and examined immediately after harvest and every 3 days intervals for the following properties:-

1. The loss in weight percentage was calculated by the following equation: Loss in weight $\%=$ Initial weight of fruit - weight of fruit at sampling date / the initial weight of the fruit X 100 .

2. Decay percentage was determined the number of decayed fruits due to fungus or any microorganism infection was recorded periodically (every 3 days) and calculated as a percentage from the total number of fruits using the following equation: $\mathrm{FDP}=$ number of decayed fruits/ total fruit number $\mathrm{x} 100$.

3. The general appearance was scaled from 9 to 1 , where $9=$ excellent, $7=$ good, $5=$ fair, $3=$ poor and 1 $=$ unsalable and fruits rating (5) or below were considered as unmarketable, as described by kader $e t$ al. (1973).

4. Fruit firmness was recorded using TA- 1000 texture analyzer instrument using a penetrating cylinder of $1 \mathrm{~mm}$ diameter. Firmness was expressed as pound per square inch $\left(\mathrm{Lb} / \mathrm{in}^{2}\right)$.

5. Total soluble solids percentage was determined by using PR- 101 digital refractometer.

6. Ascorbic acid content was determined by titration method using 2, 6 dicloro phenol indophenols as described by A.O.A.C (1990). 
7. Anthocyanins content was spectrophotometrically determined by the method described by A.O.A.C (1990).

8. Total sugars were determined using Nelson's methods (Malik and Singh, 1980), which determined colorimetrically at wavelength of $520 \mathrm{~nm}$ (Sadasivam and Manickam, 2004).

\section{Statistical Analysis:}

Data were statistically analyzed using the analysis of variance described by Snedecor and Cochran (1980). The method of Duncan multiple range test was applied for comparison between means according to Waller and Duncan (1969).

\section{Results and Discussion}

\section{Weight loss percentage:}

Data in Table (1) showed that weight loss percentage of strawberry fruits was increased considerably and consistently with the prolongation of storage period in the two seasons. These results are in agreement with those obtained by Perez et al. (1999) and Atala (2015) on strawberry fruits. Normally, the weight loss occurs during the fruit storage due to respiratory process, the transference of humidity and some processes of oxidation (Wills et al., 1998).

Concerning the effect of postharvest treatments, data revealed that there were significant differences between postharvest treatments and untreated control during storage. All postharvest treatments retained their weight during storage as compared with untreated control. Moreover, strawberry fruits which exposed to ozone gas for $30 \mathrm{~min}$. was the most effective treatment in reducing weight loss $\%$ followed by fruits which exposed to ozone gas for 20 or $40 \mathrm{~min}$. with significant differences between them in the two seasons. Fruits which exposed to ozone gas for $50 \mathrm{~min}$. were the less effective treatment in this concern. The highest value of weight loss $\%$ was recorded with untreated control. These results were achieved in the two seasons and were in agreement with Skog and Chu (2001) and Zhang et al. (2011).

Table 1: Effect of ozone treatments on weight loss percentage of strawberry fruits during storage at $0^{\circ} \mathrm{C}$ in 2017 and 2018 seasons.

\begin{tabular}{ccccccccccc}
\hline & \multicolumn{10}{c}{ Storage period (days) } \\
\hline Treatments(min) & $\mathbf{0}$ & $\mathbf{3}$ & $\mathbf{6}$ & $\mathbf{9}$ & $\mathbf{1 2}$ & $\mathbf{1 5}$ & $\mathbf{1 8}$ & $\mathbf{2 1}$ & Mean \\
\hline & & & \multicolumn{7017}{c}{} & $\mathbf{2 0 1 7}$ & & & & & \\
Control & $0.00 \mathrm{z}$ & $0.86 \mathrm{vx}$ & $2.40 \mathrm{op}$ & $5.50 \mathrm{j}$ & $12.53 \mathrm{~d}$ & $22.56 \mathrm{c}$ & $28.66 \mathrm{~b}$ & $39.13 \mathrm{a}$ & $13.95 \mathrm{~A}$ \\
$\mathbf{1 0}$ & $0.00 \mathrm{z}$ & $0.60 \mathrm{xy}$ & $1.26 \mathrm{tu}$ & $1.80 \mathrm{r}$ & $2.70 \mathrm{no}$ & $3.46 \mathrm{~m}$ & $5.60 \mathrm{ij}$ & $8.66 \mathrm{f}$ & $3.01 \mathrm{C}$ \\
$\mathbf{2 0}$ & $0.00 \mathrm{z}$ & $0.40 \mathrm{y}$ & $0.90 \mathrm{vx}$ & $1.20 \mathrm{tv}$ & $1.80 \mathrm{r}$ & $2.26 \mathrm{pq}$ & $3.80 \mathrm{~lm}$ & $6.33 \mathrm{~h}$ & $2.08 \mathrm{E}$ \\
$\mathbf{3 0}$ & $0.00 \mathrm{z}$ & $0.30 \mathrm{yz}$ & $0.56 \mathrm{xy}$ & $0.96 \mathrm{uw}$ & $1.33 \mathrm{t}$ & $1.70 \mathrm{rs}$ & $2.63 \mathrm{np}$ & $4.30 \mathrm{k}$ & $1.47 \mathrm{~F}$ \\
$\mathbf{4 0}$ & $0.00 \mathrm{z}$ & $0.43 \mathrm{y}$ & $0.96 \mathrm{u}-\mathrm{w}$ & $1.3 \mathrm{tu}$ & $1.93 \mathrm{qr}$ & $2.40 \mathrm{op}$ & $4.03 \mathrm{kl}$ & $6.76 \mathrm{~g}$ & $2.22 \mathrm{D}$ \\
$\mathbf{5 0}$ & $0.00 \mathrm{z}$ & $0.63 \mathrm{wy}$ & $1.36 \mathrm{st}$ & $1.96 \mathrm{qr}$ & $2.83 \mathrm{n}$ & $3.63 \mathrm{~m}$ & $5.93 \mathrm{i}$ & $9.63 \mathrm{e}$ & $3.25 \mathrm{~B}$ \\
Mean & $0.00 \mathrm{H}$ & $0.53 \mathrm{G}$ & $1.24 \mathrm{~F}$ & $2.12 \mathrm{E}$ & $3.85 \mathrm{D}$ & $6.00 \mathrm{C}$ & $8.44 \mathrm{~B}$ & $12.47 \mathrm{~A}$ & \\
\hline & & & & $\mathbf{2 0 1 8}$ & & & & & \\
Control & $0.00 \mathrm{y}$ & $0.80 \mathrm{t}-\mathrm{u}$ & $2.30 \mathrm{no}$ & $4.50 \mathrm{~h}$ & $8.63 \mathrm{~d}$ & $17.40 \mathrm{c}$ & $23.80 \mathrm{~b}$ & $35.70 \mathrm{a}$ & $11.64 \mathrm{~A}$ \\
$\mathbf{1 0}$ & $0.00 \mathrm{y}$ & $0.53 \mathrm{v}$ & $1.10 \mathrm{rs}$ & $1.66 \mathrm{p}$ & $2.561 \mathrm{~m}$ & $3.10 \mathrm{k}$ & $5.36 \mathrm{~g}$ & $8.50 \mathrm{~d}$ & $2.85 \mathrm{C}$ \\
$\mathbf{2 0}$ & $0.00 \mathrm{y}$ & $0.36 \mathrm{vx}$ & $0.83 \mathrm{t}$ & $1.13 \mathrm{rs}$ & $1.63 \mathrm{p}$ & $2.10 \mathrm{o}$ & $3.63 \mathrm{ij}$ & $5.80 \mathrm{f}$ & $1.93 \mathrm{E}$ \\
$\mathbf{3 0}$ & $0.00 \mathrm{y}$ & $0.23 \mathrm{xy}$ & $0.53 \mathrm{v}$ & $0.83 \mathrm{t}$ & $1.13 \mathrm{rs}$ & $1.43 \mathrm{q}$ & $2.50 \mathrm{mn}$ & $3.60 \mathrm{ij}$ & $1.28 \mathrm{~F}$ \\
$\mathbf{4 0}$ & $0.00 \mathrm{y}$ & $0.40 \mathrm{vx}$ & $0.90 \mathrm{st}$ & $1.20 \mathrm{qr}$ & $1.73 \mathrm{p}$ & $2.23 \mathrm{o}$ & $3.83 \mathrm{i}$ & $6.63 \mathrm{e}$ & $2.11 \mathrm{D}$ \\
$\mathbf{5 0}$ & $0.00 \mathrm{y}$ & $0.56 \mathrm{uv}$ & $1.26 \mathrm{qr}$ & $1.73 \mathrm{p}$ & 2.761 & $3.56 \mathrm{j}$ & $5.76 \mathrm{f}$ & $8.63 \mathrm{~d}$ & $3.03 \mathrm{~B}$ \\
Mean & $0.00 \mathrm{H}$ & $0.48 \mathrm{G}$ & $1.15 \mathrm{~F}$ & $1.84 \mathrm{E}$ & $3.07 \mathrm{D}$ & $4.97 \mathrm{C}$ & $7.48 \mathrm{~B}$ & $11.47 \mathrm{~A}$ & \\
\hline
\end{tabular}

Means in the same column having the same letter are not significantly different at 0.05 level by Duncan's multiple rang test.

Minimizing weight loss from ozone treatment during storage may be due to ozone removes exogenous ethylene from atmosphere surrounding produce by oxidizing it to ethylene glycol, which later breaks into carbon dioxide (Skog and Chu, 2001), which decreased respiration rate (Zhang et al.,2011) and consequently reduced fresh weight loss. Also, Kim et al. (2010) illustrated that $\mathrm{O}_{3}$ reduce 
weight loss because $\mathrm{O}_{3}$ inhibition of enzymatic reaction can cause a decrease in fruit respiration leading to less weight loss.

In general, the interaction between postharvest treatments and storage periods was significant effect on weight loss percentage in the two seasons. After 21 days of storage, the lowest value of weight loss was recorded from strawberry fruits which exposed to ozone gas for $30 \mathrm{~min}$. while the highest values of weight loss percentage were obtained from untreated control.

\section{Decay percentage:}

Data in Table (2) indicated that there were significant increases in decay percentage with the prolongation of storage period in the two seasons. These results were in agreement with those obtained by Perez et al. (1999) and Atala (2015) on strawberry fruits. This finding may be due to the continuous chemical and biochemical changes happened in fruits such as moisture concentration and transformation of complex compounds to simple forms of more liability to fungal infection such as solid protopectin to the soluble pectin form (Wills et al., 1981).

There were significant differences in decay percentage between postharvest treatments and control. Strawberry fruits treated with ozone gas for different periods did not show any decay during all storage periods till 21 days of storage at $0^{\circ} \mathrm{C}$ in the two seasons, while untreated control gave the highest decay $\%$. These results were achieved in the two seasons and were in agreement with Perez et al. (1999), Aday et al. (2014) and Kannaujia et al. (2019).

Suslow (1998) showed that ozone rapidly attacks bacterial cell walls and is more effective against the thick-walled spores of plant pathogens and animal parasites than chlorine, at practical and safe concentrations. Also, Thaer et al. (2013) show that ozone treatment plays a control effect on microorganism contamination and increases shelf life.

Table 2: Effect of ozone treatments on decay percentage of strawberry fruits during storage at $0^{\circ} \mathrm{C}$ in 2017 and 2018 seasons.

\begin{tabular}{ccccccccccc}
\hline & \multicolumn{10}{c}{ Storage period (days) } \\
\hline Treatments(min) & $\mathbf{0}$ & $\mathbf{3}$ & $\mathbf{6}$ & $\mathbf{9}$ & $\mathbf{1 2}$ & $\mathbf{1 5}$ & $\mathbf{1 8}$ & $\mathbf{2 1}$ & Mean \\
\hline & & & & $\mathbf{2 0 1 7}$ & & & & & \\
Control & $0.00 \mathrm{f}$ & $0.00 \mathrm{f}$ & $1.96 \mathrm{e}$ & $2.23 \mathrm{e}$ & $4.86 \mathrm{~d}$ & $8.93 \mathrm{c}$ & $18.10 \mathrm{~b}$ & $28.70 \mathrm{a}$ & $8.10 \mathrm{~A}$ \\
$\mathbf{1 0}$ & $0.00 \mathrm{f}$ & $0.00 \mathrm{f}$ & $0.00 \mathrm{f}$ & $0.00 \mathrm{f}$ & $0.00 \mathrm{f}$ & $0.00 \mathrm{f}$ & $0.00 \mathrm{f}$ & $0.00 \mathrm{f}$ & $0.00 \mathrm{~B}$ \\
$\mathbf{2 0}$ & $0.00 \mathrm{f}$ & $0.00 \mathrm{f}$ & $0.00 \mathrm{f}$ & $0.00 \mathrm{f}$ & $0.00 \mathrm{f}$ & $0.00 \mathrm{f}$ & $0.00 \mathrm{f}$ & $0.00 \mathrm{f}$ & $0.00 \mathrm{~B}$ \\
$\mathbf{3 0}$ & $0.00 \mathrm{f}$ & $0.00 \mathrm{f}$ & $0.00 \mathrm{f}$ & $0.00 \mathrm{f}$ & $0.00 \mathrm{f}$ & $0.00 \mathrm{f}$ & $0.00 \mathrm{f}$ & $0.00 \mathrm{f}$ & $0.00 \mathrm{~B}$ \\
$\mathbf{4 0}$ & $0.00 \mathrm{f}$ & $0.00 \mathrm{f}$ & $0.00 \mathrm{f}$ & $0.00 \mathrm{f}$ & $0.00 \mathrm{f}$ & $0.00 \mathrm{f}$ & $0.00 \mathrm{f}$ & $0.00 \mathrm{f}$ & $0.00 \mathrm{~B}$ \\
$\mathbf{5 0}$ & $0.00 \mathrm{f}$ & $0.00 \mathrm{f}$ & $0.00 \mathrm{f}$ & $0.00 \mathrm{f}$ & $0.00 \mathrm{f}$ & $0.00 \mathrm{f}$ & $0.00 \mathrm{f}$ & $0.00 \mathrm{f}$ & $0.00 \mathrm{~B}$ \\
Mean & $0.00 \mathrm{E}$ & $0.00 \mathrm{E}$ & $0.33 \mathrm{DE}$ & $0.37 \mathrm{DE}$ & $0.81 \mathrm{CD}$ & $1.48 \mathrm{C}$ & $3.01 \mathrm{~B}$ & $4.78 \mathrm{~A}$ & \\
\hline & & & & $\mathbf{2 0 1 8}$ & & & & & \\
Control & $0.00 \mathrm{f}$ & $0.00 \mathrm{f}$ & $1.76 \mathrm{e}$ & $2.10 \mathrm{e}$ & $4.33 \mathrm{~d}$ & $8.70 \mathrm{c}$ & $17.70 \mathrm{~b}$ & $26.76 \mathrm{a}$ & $7.67 \mathrm{~A}$ \\
$\mathbf{1 0}$ & $0.00 \mathrm{f}$ & $0.00 \mathrm{f}$ & $0.00 \mathrm{f}$ & $0.00 \mathrm{f}$ & $0.00 \mathrm{f}$ & $0.00 \mathrm{f}$ & $0.00 \mathrm{f}$ & $0.00 \mathrm{f}$ & $0.00 \mathrm{~B}$ \\
$\mathbf{2 0}$ & $0.00 \mathrm{f}$ & $0.00 \mathrm{f}$ & $0.00 \mathrm{f}$ & $0.00 \mathrm{f}$ & $0.00 \mathrm{f}$ & $0.00 \mathrm{f}$ & $0.00 \mathrm{f}$ & $0.00 \mathrm{f}$ & $0.00 \mathrm{~B}$ \\
$\mathbf{3 0}$ & $0.00 \mathrm{f}$ & $0.00 \mathrm{f}$ & $0.00 \mathrm{f}$ & $0.00 \mathrm{f}$ & $0.00 \mathrm{f}$ & $0.00 \mathrm{f}$ & $0.00 \mathrm{f}$ & $0.00 \mathrm{f}$ & $0.00 \mathrm{~B}$ \\
$\mathbf{4 0}$ & $0.00 \mathrm{f}$ & $0.00 \mathrm{f}$ & $0.00 \mathrm{f}$ & $0.00 \mathrm{f}$ & $0.00 \mathrm{f}$ & $0.00 \mathrm{f}$ & $0.00 \mathrm{f}$ & $0.00 \mathrm{f}$ & $0.00 \mathrm{~B}$ \\
$\mathbf{5 0}$ & $0.00 \mathrm{f}$ & $0.00 \mathrm{f}$ & $0.00 \mathrm{f}$ & $0.00 \mathrm{f}$ & $0.00 \mathrm{f}$ & $0.00 \mathrm{f}$ & $0.00 \mathrm{f}$ & $0.00 \mathrm{f}$ & $0.00 \mathrm{~B}$ \\
Mean & $0.00 \mathrm{E}$ & $0.00 \mathrm{E}$ & $0.29 \mathrm{DE}$ & $0.35 \mathrm{DE}$ & $0.72 \mathrm{D}$ & $1.45 \mathrm{C}$ & $2.95 \mathrm{~B}$ & $4.46 \mathrm{~A}$ & \\
\hline
\end{tabular}

Means in the same column having the same letter are not significantly different at 0.05 level by Duncan's multiple rang test.

\section{General appearance (score):}

Data in Table (3) showed that general appearance (score) of strawberries fruits was significant decreased with the prolongation of storage period in both seasons. These results were in agreement with those obtained by Ali et al. (2011) and Atala (2015). Such decrease in general appearance of fruits, mostly may be due to a slight dryness of the fruit surface, instead of translucency or macroscopic decay, as reported by Atress and Attia (2011).

Concerning the effect of postharvest treatments, data revealed that there were significant differences between postharvest treatments and untreated control during storage. Strawberry fruits treated with ozone treatments had significantly the highest score of appearance as compared with 
untreated control. However, strawberry fruits which exposed to ozone gas for $30 \mathrm{~min}$. was the most effective treatment for maintaining general appearance, followed by fruits which exposed to ozone gas for 20, $40 \mathrm{~min}$. with no significant differences between them in the two seasons, while untreated control recorded the lowest ones in this concern. These results were achieved in the two seasons and were in agreement with Perez et al. (1999), Thaer et al. (2013) and Aday et al. (2014).

Table 3: Effect of ozone treatments on general appearance (score) of strawberry fruits during storage at $0^{\circ} \mathrm{C}$ in 2017 and 2018 seasons.

\begin{tabular}{cccccccccc}
\hline & \multicolumn{10}{c}{ Storage period (days) } \\
\hline Treatments(min) & $\mathbf{0}$ & $\mathbf{3}$ & $\mathbf{6}$ & $\mathbf{9}$ & $\mathbf{1 2}$ & $\mathbf{1 5}$ & $\mathbf{1 8}$ & $\mathbf{2 1}$ & Mean \\
\hline Control & $9.00 \mathrm{a}$ & $8.33 \mathrm{de}$ & $6.33 \mathrm{de}$ & $5.66 \mathrm{ef}$ & $4.33 \mathrm{gh}$ & $3.66 \mathrm{hi}$ & $3.00 \mathrm{i}$ & $1.00 \mathrm{j}$ & $5.16 \mathrm{E}$ \\
$\mathbf{1 0}$ & $9.00 \mathrm{a}$ & $9.00 \mathrm{a}$ & $9.00 \mathrm{a}$ & $8.33 \mathrm{ab}$ & $7.66 \mathrm{bc}$ & $7.00 \mathrm{~cd}$ & $5.66 \mathrm{ef}$ & $5.00 \mathrm{fg}$ & $7.58 \mathrm{C}$ \\
$\mathbf{2 0}$ & $9.00 \mathrm{a}$ & $9.00 \mathrm{a}$ & $9.00 \mathrm{a}$ & $9.00 \mathrm{a}$ & $9.00 \mathrm{a}$ & $8.33 \mathrm{ab}$ & $7.00 \mathrm{~cd}$ & $6.33 \mathrm{de}$ & $8.33 \mathrm{~B}$ \\
$\mathbf{3 0}$ & $9.00 \mathrm{a}$ & $9.00 \mathrm{a}$ & $9.00 \mathrm{a}$ & $9.00 \mathrm{a}$ & $9.00 \mathrm{a}$ & $9.00 \mathrm{a}$ & $8.33 \mathrm{ab}$ & $7.00 \mathrm{~cd}$ & $8.66 \mathrm{~A}$ \\
$\mathbf{4 0}$ & $9.00 \mathrm{a}$ & $9.00 \mathrm{a}$ & $9.00 \mathrm{a}$ & $9.00 \mathrm{a}$ & $8.33 \mathrm{ab}$ & $7.66 \mathrm{bc}$ & $6.33 \mathrm{de}$ & $5.66 \mathrm{ef}$ & $8.00 \mathrm{~B}$ \\
$\mathbf{5 0}$ & $9.00 \mathrm{a}$ & $9.00 \mathrm{a}$ & $8.33 \mathrm{ab}$ & $7.66 \mathrm{bc}$ & $7.00 \mathrm{~cd}$ & $6.33 \mathrm{de}$ & $5.00 \mathrm{fg}$ & $4.30 \mathrm{gh}$ & $7.08 \mathrm{D}$ \\
Mean & $9.00 \mathrm{~A}$ & $8.88 \mathrm{~A}$ & $8.44 \mathrm{~B}$ & $8.11 \mathrm{~B}$ & $7.55 \mathrm{C}$ & $7.00 \mathrm{D}$ & $5.88 \mathrm{E}$ & $4.88 \mathrm{~F}$ & \\
\hline & & & & $\mathbf{2 0 1 8}$ & & & & & \\
Control & $9.00 \mathrm{a}$ & $9.00 \mathrm{a}$ & $7.00 \mathrm{~cd}$ & $6.33 \mathrm{de}$ & $5.00 \mathrm{fg}$ & $4.33 \mathrm{~g}$ & $3.00 \mathrm{~h}$ & $1.00 \mathrm{i}$ & $5.58 \mathrm{E}$ \\
$\mathbf{1 0}$ & $9.00 \mathrm{a}$ & $9.00 \mathrm{a}$ & $9.00 \mathrm{a}$ & $8.33 \mathrm{ab}$ & $7.66 \mathrm{bc}$ & $7.00 \mathrm{~cd}$ & $5.66 \mathrm{ef}$ & $5.00 \mathrm{fg}$ & $7.58 \mathrm{C}$ \\
$\mathbf{2 0}$ & $9.00 \mathrm{a}$ & $9.00 \mathrm{a}$ & $9.00 \mathrm{a}$ & $9.00 \mathrm{a}$ & $9.00 \mathrm{a}$ & $8.33 \mathrm{ab}$ & $7.00 \mathrm{~cd}$ & $6.33 \mathrm{de}$ & $8.33 \mathrm{~B}$ \\
$\mathbf{3 0}$ & $9.00 \mathrm{a}$ & $9.00 \mathrm{a}$ & $9.00 \mathrm{a}$ & $9.00 \mathrm{a}$ & $9.00 \mathrm{a}$ & $9.00 \mathrm{a}$ & $8.33 \mathrm{ab}$ & $7.66 \mathrm{bc}$ & $8.75 \mathrm{~A}$ \\
$\mathbf{4 0}$ & $9.00 \mathrm{a}$ & $9.00 \mathrm{a}$ & $9.00 \mathrm{a}$ & $9.00 \mathrm{a}$ & $8.33 \mathrm{ab}$ & $7.66 \mathrm{bc}$ & $6.33 \mathrm{de}$ & $5.66 \mathrm{ef}$ & $8.00 \mathrm{~B}$ \\
$\mathbf{5 0}$ & $9.00 \mathrm{a}$ & $9.00 \mathrm{a}$ & $8.33 \mathrm{ab}$ & $7.66 \mathrm{bc}$ & $7.00 \mathrm{~cd}$ & $6.33 \mathrm{de}$ & $5.00 \mathrm{fg}$ & $4.33 \mathrm{~g}$ & $7.08 \mathrm{D}$ \\
$\mathbf{M e a n}$ & $9.00 \mathrm{~A}$ & $9.00 \mathrm{~A}$ & $8.55 \mathrm{AB}$ & $8.22 \mathrm{~B}$ & $7.66 \mathrm{C}$ & $7.11 \mathrm{D}$ & $5.88 \mathrm{E}$ & $5.00 \mathrm{~F}$ & \\
\hline
\end{tabular}

Means in the same column having the same letter are not significantly different at 0.05 level by Duncan's multiple rang test.

Ozone maintaining postharvest quality of fruit by oxidizing ethylene produced and reduced the respiration rate during the ripening process. Reducing the ethylene level extending the shelf life of many ethylene sensitive fruits and vegetables and reduces the shrinking of product during storage (Jaksch et al., 2004 and Shalluf et al., 2007). Also, ozone treatment markedly reduction in respiration rate that retarded deterioration and maintained the keeping quality attributes for a longer period (Mshraky, 2017).

In general, the interaction between postharvest treatments and storage periods was significant in the two seasons. Results recorded that strawberry fruits which exposed to ozone gas for $30 \mathrm{~min}$. showed the best appearance and did not show any changes in GA and showed excellent appearance until 18 days and rated good appearance at the end of storage period, while ozone treatment for $20 \mathrm{~min}$. gave good appearance after 18 days of storage and dropped to fair appearance at the end of storage period. On the other hand, untreated control had the unsalable appearance after 21 days of storage at $0^{\circ} \mathrm{C}$.

\section{Fruit firmness:}

Data in Table (4) indicated that there was a significant reduction in fruit firmness of strawberry by the prolongation of storage period in the two seasons. Similar results were obtained by Ali et al. (2011), Thaer et al. (2013) and Atala (2015) on strawberry fruits. The decline in firmness may be due to the gradual breakdown of proto-pectin to lower molecular fractions which are more soluble in water and this directly correlated with the rate of softening of the fruits (Wills et al., 1998). Nogata et al. (1993) cleared that the softening of strawberry is mainly due to the presence of polygalacturonase which solubilizes and degrades the cell wall polyuronides. Also, Koh and Melton (2004) found that softening of strawberry fruits is mainly due to loss of cell wall material.

Concerning the effect of postharvest treatments, data revealed that all ozone treatments had a significant effect on fruit firmness as compared with untreated control during storage in the two seasons. However, strawberry fruits which exposed to ozone gas for $30 \mathrm{~min}$. gave the highest value of fruit firmness during storage, followed by ozone treatments for 20 and $40 \mathrm{~min}$. with no significant differences between them, while the other treatments were less effective in this concern. The lowest value of fruit 
firmness was obtained from untreated control. These results were achieved in the two seasons and were in agreement with those obtained by Perez et al. (1999), Aday et al. (2014) and Kannaujia et al. (2019).

Several studies demonstrated that ozone treatments may reduce the activity of firmness-related enzymes generally enhanced during postharvest life of fruit and vegetable (Costa et al., 2006). In general, ozone treatment inhibited PAL activity and increased cell wall phenolic compounds (An et al., 2006).

In general, the interaction between postharvest treatments and storage periods was significant in the two seasons. After 21 days at $0^{\circ} \mathrm{C}$, strawberry fruits which exposed to ozone gas for $30 \mathrm{~min}$. were the most obvious in maintaining fruit firmness at the end of storage period. The lowest value of fruit firmness was obtained from untreated control at the same period in the two seasons.

Table 4: Effect of ozone treatments on fruit firmness (Lb/in2) of strawberry fruits during storage at $0^{\circ} \mathrm{C}$ in 2017 and 2018 seasons.

\begin{tabular}{cccccccccc}
\hline & \multicolumn{10}{c}{ Storage period (days) } \\
\hline Treatments(min) & $\mathbf{0}$ & $\mathbf{3}$ & $\mathbf{6}$ & $\mathbf{9}$ & $\mathbf{1 2}$ & $\mathbf{1 5}$ & $\mathbf{1 8}$ & $\mathbf{2 1}$ & Mean \\
\hline & & & & $\mathbf{2 0 1 7}$ & & & & & \\
Control & $5.86 \mathrm{a}$ & $5.36 \mathrm{~d}-\mathrm{f}$ & $4.90 \mathrm{~g}-\mathrm{i}$ & $4.40 \mathrm{~lm}$ & $3.76 \mathrm{p}-\mathrm{r}$ & $3.23 \mathrm{~s}$ & $2.60 \mathrm{t}$ & $1.76 \mathrm{u}$ & $3.98 \mathrm{D}$ \\
$\mathbf{1 0}$ & $5.86 \mathrm{a}$ & $5.46 \mathrm{bd}$ & $5.10 \mathrm{f}-\mathrm{h}$ & $4.80 \mathrm{hk}$ & $4.50 \mathrm{~km}$ & $4.23 \mathrm{mo}$ & $3.96 \mathrm{op}$ & $3.63 \mathrm{qr}$ & $4.69 \mathrm{C}$ \\
$\mathbf{2 0}$ & $5.86 \mathrm{a}$ & $5.63 \mathrm{ad}$ & $5.43 \mathrm{ce}$ & $5.13 \mathrm{eg}$ & $4.83 \mathrm{gj}$ & $4.56 \mathrm{j} 1$ & $4.331-\mathrm{n}$ & $4.06 \mathrm{np}$ & $4.98 \mathrm{~B}$ \\
$\mathbf{3 0}$ & $5.86 \mathrm{a}$ & $5.76 \mathrm{ab}$ & $5.70 \mathrm{ac}$ & $5.56 \mathrm{ad}$ & $5.46 \mathrm{bd}$ & $5.33 \mathrm{df}$ & $5.13 \mathrm{eg}$ & $4.93 \mathrm{gi}$ & $5.47 \mathrm{~A}$ \\
$\mathbf{4 0}$ & $5.86 \mathrm{a}$ & $5.53 \mathrm{bd}$ & $5.40 \mathrm{ce}$ & $5.06 \mathrm{fh}$ & $4.73 \mathrm{ik}$ & $4.50 \mathrm{~km}$ & $4.26 \mathrm{lo}$ & $4.00 \mathrm{op}$ & $4.92 \mathrm{~B}$ \\
$\mathbf{5 0}$ & $5.86 \mathrm{a}$ & $5.40 \mathrm{ce}$ & $5.03 \mathrm{gi}$ & $4.73 \mathrm{ik}$ & $4.401 \mathrm{~m}$ & $4.20 \mathrm{mo}$ & $3.83 \mathrm{pq}$ & $3.50 \mathrm{rs}$ & $4.62 \mathrm{C}$ \\
Mean & $5.86 \mathrm{~A}$ & $5.52 \mathrm{~B}$ & $5.26 \mathrm{C}$ & $4.95 \mathrm{D}$ & $4.61 \mathrm{E}$ & $4.34 \mathrm{~F}$ & $4.02 \mathrm{G}$ & $3.65 \mathrm{H}$ & \\
\hline & & & & $\mathbf{2 0 1 8}$ & & & & & \\
Control & $5.93 \mathrm{a}$ & $5.40 \mathrm{~d}-\mathrm{i}$ & $5.13 \mathrm{i}-\mathrm{k}$ & $4.46 \mathrm{o}-\mathrm{r}$ & $3.80 \mathrm{vx}$ & $3.26 \mathrm{y}$ & $2.73 \mathrm{z}$ & $1.80 \mathrm{~A}$ & $4.06 \mathrm{D}$ \\
$\mathbf{1 0}$ & $5.93 \mathrm{a}$ & $5.56 \mathrm{c}-\mathrm{f}$ & $5.36 \mathrm{e}-\mathrm{i}$ & $5.00 \mathrm{j}-1$ & $4.70 \mathrm{mo}$ & $4.36 \mathrm{p}-\mathrm{s}$ & $4.06 \mathrm{t}-\mathrm{v}$ & $3.76 \mathrm{wx}$ & $4.84 \mathrm{C}$ \\
$\mathbf{2 0}$ & $5.93 \mathrm{a}$ & $5.73 \mathrm{ac}$ & $5.50 \mathrm{cg}$ & $5.30 \mathrm{f}-\mathrm{i}$ & $5.03 \mathrm{j}-1$ & $4.801-\mathrm{n}$ & $4.50 \mathrm{oq}$ & $4.20 \mathrm{r}-\mathrm{t}$ & $5.12 \mathrm{~B}$ \\
$\mathbf{3 0}$ & $5.93 \mathrm{a}$ & $5.86 \mathrm{ab}$ & $5.76 \mathrm{ac}$ & $5.66 \mathrm{ad}$ & $5.56 \mathrm{c}-\mathrm{f}$ & $5.43 \mathrm{dh}$ & $5.20 \mathrm{hk}$ & $5.00 \mathrm{j}-1$ & $5.55 \mathrm{~A}$ \\
$\mathbf{4 0}$ & $5.93 \mathrm{a}$ & $5.60 \mathrm{be}$ & $5.43 \mathrm{dh}$ & $5.23 \mathrm{~g}-\mathrm{j}$ & $4.93 \mathrm{~km}$ & $4.70 \mathrm{mo}$ & $4.40 \mathrm{ps}$ & $4.16 \mathrm{~s}-\mathrm{u}$ & $5.05 \mathrm{~B}$ \\
$\mathbf{5 0}$ & $5.93 \mathrm{a}$ & $5.53 \mathrm{c}-\mathrm{f}$ & $5.33 \mathrm{e}-\mathrm{i}$ & $4.93 \mathrm{~km}$ & $4.60 \mathrm{np}$ & $4.26 \mathrm{q}-\mathrm{t}$ & $3.90 \mathrm{uw}$ & $3.56 \mathrm{x}$ & $4.75 \mathrm{C}$ \\
Mean & $5.93 \mathrm{~A}$ & $5.61 \mathrm{~B}$ & $5.42 \mathrm{C}$ & $5.10 \mathrm{D}$ & $4.77 \mathrm{E}$ & $4.47 \mathrm{~F}$ & $4.13 \mathrm{G}$ & $3.75 \mathrm{H}$ & \\
\hline
\end{tabular}

Means in the same column having the same letter are not significantly different at 0.05 level by Duncan's multiple rang test.

\section{Total soluble solids percentage:}

Data in Table (5) indicated that total soluble solids of strawberry fruits were significantly decreased with the prolongation of storage period in both seasons. Similar results were obtained by Mishra and Kar (2014) on strawberry fruits. The loss of total soluble solids during the storage period is natural, as sugars are the primary constituent of the soluble solid contents of product, consumed by respiration and used for the metabolic activities of the fruits (Wills et al., 1998).

Regarding the effect of postharvest treatments, data revealed that there were significant differences between postharvest treatments and untreated control in TSS \% of strawberry fruits during storage. Strawberry fruits which exposed to ozone gas for $30 \mathrm{~min}$. retained more TSS \%, followed by ozone treatments for 20 and $40 \mathrm{~min}$. with no significant differences between them in the second season. Untreated control gave the lowest value of TSS \%. These results were achieved in the two seasons and were in agreement with those obtained by Perez et al. (1999), Aday et al. (2014) and Kannaujia et al. (2019).

The positive effect on total soluble solids by ozone treatment may be due to the delaying of metabolic activity and reduced respiration rate and vital process, this reflected to reducing the loss of TSS during storage and degradation of fruits and over senescence (Shalluf et al., 2007).

In general, the interaction between postharvest treatments and storage periods was significant in the two seasons. After 21 days at $0^{\circ} \mathrm{C}$, strawberry fruits which exposed to ozone gas for $30 \mathrm{~min}$. resulted in significantly higher TSS \%, followed by ozone treatments for 20 or $40 \mathrm{~min}$. with no significant differences between them, while untreated control gave the lowest ones in the same period. These results were achieved in the two seasons. 
Table 5: Effect of ozone treatments on total soluble solids (\%) of strawberry fruits during storage at $0^{\circ} \mathrm{C}$ in 2017 and 2018 seasons.

\begin{tabular}{|c|c|c|c|c|c|c|c|c|c|}
\hline \multicolumn{10}{|c|}{ Storage period (days) } \\
\hline $\begin{array}{l}\text { Treatments } \\
\text { (min) }\end{array}$ & $\mathbf{0}$ & 3 & 6 & 9 & 12 & 15 & 18 & 21 & Mean \\
\hline \multicolumn{10}{|c|}{2017} \\
\hline Control & $12.53 \mathrm{a}$ & $11.53 \mathrm{gi}$ & $10.56 \mathrm{lo}$ & $9.63 \mathrm{r}$ & $8.33 \mathrm{~s}$ & $7.16 \mathrm{t}$ & $6.00 \mathrm{u}$ & $5.00 \mathrm{v}$ & $8.84 \mathrm{~F}$ \\
\hline 10 & $12.53 \mathrm{a}$ & $11.96 \mathrm{ce}$ & 11.46hj & $10.90 \mathrm{kl}$ & $10.30 \mathrm{np}$ & $9.70 \mathrm{q}-\mathrm{r}$ & $8.66 \mathrm{~s}$ & $7.43 \mathrm{t}$ & $10.37 \mathrm{D}$ \\
\hline 20 & $12.53 \mathrm{a}$ & $12.26 \mathrm{ac}$ & $11.86 \mathrm{dg}$ & 11.40hj & $10.90 \mathrm{kl}$ & $10.50 \mathrm{mo}$ & $10.26 o p$ & $9.70 \mathrm{qr}$ & $11.17 \mathrm{~B}$ \\
\hline 30 & $12.53 \mathrm{a}$ & $12.40 \mathrm{ab}$ & $12.16 \mathrm{bd}$ & $11.86 \mathrm{dg}$ & $11.63 \mathrm{eh}$ & $11.43 \mathrm{hj}$ & $11.13 \mathrm{jk}$ & $10.46 \mathrm{mo}$ & $11.70 \mathrm{~A}$ \\
\hline 40 & $12.53 \mathrm{a}$ & $12.13 \mathrm{bd}$ & $11.60 \mathrm{fh}$ & $11.16 \mathrm{jk}$ & $10.63 \ln$ & $10.36 \mathrm{np}$ & $10.00 \mathrm{pq}$ & $9.50 \mathrm{r}$ & $10.99 \mathrm{C}$ \\
\hline 50 & $12.53 \mathrm{a}$ & $11.90 \mathrm{df}$ & $11.23 \mathrm{ik}$ & $10.76 \mathrm{~lm}$ & $10.06 \mathrm{pq}$ & $9.46 \mathrm{r}$ & $8.60 \mathrm{~s}$ & $7.26 \mathrm{t}$ & $10.22 \mathrm{E}$ \\
\hline Mean & $12.53 \mathrm{~A}$ & $12.03 \mathrm{~B}$ & $11.48 \mathrm{C}$ & $10.95 \mathrm{D}$ & $10.31 \mathrm{E}$ & $9.77 \mathrm{~F}$ & $9.11 \mathrm{G}$ & $8.22 \mathrm{H}$ & \\
\hline \multicolumn{10}{|c|}{2018} \\
\hline Control & $12.60 \mathrm{a}$ & $11.90 \mathrm{e}-\mathrm{g}$ & $10.90 \mathrm{kl}$ & $9.80 \mathrm{st}$ & $8.43 \mathrm{v}$ & $7.53 x$ & $6.26 y$ & $5.13 \mathrm{z}$ & $9.07 \mathrm{E}$ \\
\hline 10 & $12.60 \mathrm{a}$ & $12.06 \mathrm{c}-\mathrm{e}$ & $11.53 \mathrm{hi}$ & $10.96 \mathrm{kl}$ & $10.40 \mathrm{op}$ & $10.16 \mathrm{p}-\mathrm{r}$ & $9.33 u$ & 7.9 & $10.62 \mathrm{C}$ \\
\hline 20 & $12.60 \mathrm{a}$ & $12.43 \mathrm{ab}$ & $11.93 \mathrm{e}-\mathrm{f}$ & $11.63 \mathrm{~g}-\mathrm{i}$ & $11.00 \mathrm{jk}$ & $10.56 \mathrm{~m}-\mathrm{o}$ & 10.46op & $10.03 q-s$ & $11.33 \mathrm{~B}$ \\
\hline 30 & $12.60 \mathrm{a}$ & $12.46 \mathrm{ab}$ & $12.26 \mathrm{~b}-\mathrm{d}$ & $12.00 \mathrm{cf}$ & $11.70 \mathrm{f}-\mathrm{h}$ & $11.50 \mathrm{~h}-\mathrm{j}$ & $11.20 \mathrm{jk}$ & 10.50 no & $11.77 \mathrm{~A}$ \\
\hline 40 & $12.60 \mathrm{a}$ & $12.30 \mathrm{a}-\mathrm{c}$ & $11.90 \mathrm{~d}-\mathrm{g}$ & $11.56 \mathrm{hi}$ & $10.831-\mathrm{m}$ & $10.43 \mathrm{op}$ & 10.36op & $9.90 \mathrm{r}-\mathrm{t}$ & $11.23 \mathrm{~B}$ \\
\hline 50 & $12.60 \mathrm{a}$ & $11.96 \mathrm{~d}-\mathrm{f}$ & $11.36 \mathrm{ij}$ & $10.801-\mathrm{n}$ & $10.30 \mathrm{o}-\mathrm{q}$ & $9.70 \mathrm{t}$ & $9.16 \mathrm{u}$ & $7.70 \mathrm{wx}$ & $10.45 \mathrm{D}$ \\
\hline Mean & $12.60 \mathrm{~A}$ & $12.18 \mathrm{~B}$ & $11.65 \mathrm{C}$ & $11.12 \mathrm{D}$ & $10.44 \mathrm{E}$ & $9.98 \mathrm{~F}$ & $9.46 \mathrm{G}$ & $8.53 \mathrm{H}$ & \\
\hline
\end{tabular}

Means in the same column having the same letter are not significantly different at 0.05 level by Duncan's multiple rang test.

\section{Ascorbic acid content:}

Data in Table (6) showed that ascorbic acid content of strawberry fruits was significantly decreased with the prolongation of storage period in both seasons. Similar results were obtained by Lee and Kader (2000), Mishra and Kar (2014) and Atala (2015) on strawberry fruits. The reduction in ascorbic acid contents during storage may be due to the higher rate of sugar loss through respiration than the water loss through transpiration (Wills et al., 1998).

Table 6: Effect of ozone treatments on ascorbic acid content (mg/100g FW) of strawberry fruits during storage at $0^{\circ} \mathrm{C}$ in 2017 and 2018 seasons.

\begin{tabular}{cccccccccc}
\hline & & \multicolumn{7}{c}{ Storage period (days) } \\
\hline $\begin{array}{c}\text { Treatments } \\
\text { (min) }\end{array}$ & $\mathbf{0}$ & $\mathbf{3}$ & $\mathbf{6}$ & $\mathbf{9}$ & $\mathbf{1 2}$ & $\mathbf{1 5}$ & $\mathbf{1 8}$ & $\mathbf{2 1}$ & Mean \\
\hline & & & & & 2017 & & & & \\
Control & $95.83 \mathrm{a}$ & $93.43 \mathrm{r}$ & $89.23 \mathrm{y}$ & $80.93 \mathrm{z}$ & $68.03 \mathrm{~A}$ & $56.03 \mathrm{~B}$ & $43.13 \mathrm{C}$ & $30.23 \mathrm{D}$ & $69.60 \mathrm{~F}$ \\
$\mathbf{1 0}$ & $95.83 \mathrm{a}$ & $95.36 \mathrm{ef}$ & $95.03 \mathrm{~h}$ & $94.63 \mathrm{kl}$ & $94.23 \mathrm{op}$ & $93.43 \mathrm{r}$ & $92.33 \mathrm{u}$ & $90.50 \mathrm{w}$ & $93.90 \mathrm{D}$ \\
$\mathbf{2 0}$ & $95.83 \mathrm{a}$ & $95.63 \mathrm{bc}$ & $95.33 \mathrm{ef}$ & $95.03 \mathrm{~h}$ & $94.73 \mathrm{jk}$ & $94.33 \mathrm{no}$ & $93.63 \mathrm{q}$ & $92.53 \mathrm{t}$ & $94.63 \mathrm{~B}$ \\
$\mathbf{3 0}$ & $95.83 \mathrm{a}$ & $95.73 \mathrm{ab}$ & $95.53 \mathrm{~cd}$ & $95.23 \mathrm{fg}$ & $94.93 \mathrm{i}$ & $94.73 \mathrm{jk}$ & $94.63 \mathrm{kl}$ & $94.33 \mathrm{no}$ & $95.12 \mathrm{~A}$ \\
$\mathbf{4 0}$ & $95.83 \mathrm{a}$ & $95.43 \mathrm{de}$ & $95.13 \mathrm{gh}$ & $94.86 \mathrm{ji}$ & $94.531 \mathrm{~m}$ & $94.13 \mathrm{p}$ & $93.43 \mathrm{r}$ & $91.63 \mathrm{z}$ & $94.37 \mathrm{C}$ \\
$\mathbf{5 0}$ & $95.83 \mathrm{a}$ & $95.33 \mathrm{ef}$ & $94.93 \mathrm{i}$ & $94.531 \mathrm{~m}$ & $94.10 \mathrm{p}$ & $93.26 \mathrm{~s}$ & $92.23 \mathrm{u}$ & $90.33 \mathrm{x}$ & $93.82 \mathrm{E}$ \\
Mean & $95.83 \mathrm{~A}$ & $95.15 \mathrm{~B}$ & $94.20 \mathrm{C}$ & $92.53 \mathrm{D}$ & $90.09 \mathrm{E}$ & $87.65 \mathrm{~F}$ & $84.90 \mathrm{G}$ & $81.59 \mathrm{H}$ & \\
\hline & & & & $\mathbf{2 0 1 8}$ & & & & & \\
Control & $96.33 \mathrm{a}$ & $93.63 \mathrm{op}$ & $90.23 \mathrm{y}$ & $85.50 \mathrm{z}$ & $78.23 \mathrm{~A}$ & $62.73 \mathrm{~B}$ & $50.63 \mathrm{C}$ & $31.03 \mathrm{D}$ & $73.54 \mathrm{~F}$ \\
$\mathbf{1 0}$ & $96.33 \mathrm{a}$ & $95.93 \mathrm{~b}-\mathrm{d}$ & $95.63 \mathrm{hi}$ & $95.23 \mathrm{~m}$ & $94.53 \mathrm{pq}$ & $93.73 \mathrm{r}$ & $92.83 \mathrm{t}$ & $91.73 \mathrm{x}$ & $94.49 \mathrm{D}$ \\
$\mathbf{2 0}$ & $96.33 \mathrm{a}$ & $96.03 \mathrm{~b}$ & $95.83 \mathrm{c}-\mathrm{e}$ & $95.43 \mathrm{kl}$ & $95.03 \mathrm{n}$ & $94.73 \mathrm{o}$ & $93.73 \mathrm{r}$ & $92.83 \mathrm{t}$ & $94.99 \mathrm{~B}$ \\
$\mathbf{3 0}$ & $96.33 \mathrm{a}$ & $96.23 \mathrm{a}$ & $96.03 \mathrm{~b}$ & $95.80 \mathrm{~d}-\mathrm{f}$ & $95.53 \mathrm{jk}$ & $95.23 \mathrm{~m}$ & $95.00 \mathrm{n}$ & $94.63 \mathrm{op}$ & $95.60 \mathrm{~A}$ \\
$\mathbf{4 0}$ & $96.33 \mathrm{a}$ & $95.96 \mathrm{bc}$ & $95.73 \mathrm{e}-\mathrm{g}$ & $95.331 \mathrm{~m}$ & $94.93 \mathrm{n}$ & $94.63 \mathrm{op}$ & $93.66 \mathrm{rs}$ & $92.13 \mathrm{~V}$ & $94.84 \mathrm{C}$ \\
$\mathbf{5 0}$ & $96.33 \mathrm{a}$ & $95.86 \mathrm{f}-\mathrm{h}$ & $95.43 \mathrm{kl}$ & $94.93 \mathrm{n}$ & $94.43 \mathrm{q}$ & $93.56 \mathrm{~s}$ & $92.63 \mathrm{u}$ & $91.03 \mathrm{x}$ & $94.27 \mathrm{E}$ \\
Mean & $96.33 \mathrm{~A}$ & $95.61 \mathrm{~B}$ & $94.81 \mathrm{C}$ & $93.70 \mathrm{D}$ & $92.11 \mathrm{E}$ & $89.10 \mathrm{~F}$ & $86.41 \mathrm{G}$ & $82.23 \mathrm{H}$ & \\
\hline
\end{tabular}

Means in the same column having the same letter are not significantly different at 0.05 level by Duncan's multiple rang test.

Regarding the effect of postharvest treatments, data showed that all ozone treatments were significantly effective in preventing ascorbic acid degradation during storage as compared with untreated control. Moreover, strawberry fruits which exposed to ozone gas for 30 and $20 \mathrm{~min}$. were the 
most effective treatments in maintaining ascorbic acid content with significant differences between them, followed by ozone treatments for 40 or $10 \mathrm{~min}$. with significant differences between them. The lowest values resulted in untreated control. These results were achieved in the two seasons and were in agreement with those obtained by Perez et al. (1999), Aday et al. (2014) and Kannaujia et al. (2019).

Perez et al. (1999) revealed that changes in vitamin C content of strawberry fruits treated with ozone can be attributed to the activation of an antioxidative system that promotes the biosynthesis of vitamin $\mathrm{C}$ from the carbohydrate pool.

In general, the interaction between postharvest treatments and storage periods was significant in the two seasons. After 21 days at $0^{\circ} \mathrm{C}$, strawberry fruits which exposed to ozone gas for $30 \mathrm{~min}$. resulted in significantly higher ascorbic acid content, followed by ozone treatments for 20 or $40 \mathrm{~min}$. with significant differences between them, while untreated control gave the lowest ones in the same period in the two seasons.

\section{Anthocyanins content:}

Data in Table (7) demonstrate that anthocyanins content of strawberry fruits were significantly increased with prolongation of storage period till the end of storage in both seasons. These results are in agreement with those obtained by Kalt and McDonald (1996) and Atala (2015) on strawberry fruits. The increase in anthocyanins concentration during strawberry storage due to continuous synthesis of this pigment (Almenar et al., 2007).

Concerning the effect of postharvest treatments, data revealed that there were significant differences between ozone treatments and untreated control during storage. However, strawberry fruits which exposed to ozone gas for $30 \mathrm{~min}$. gave the lowest values in anthocyanins content during storage followed by ozone treatments for 20 or $40 \mathrm{~min}$. with significant differences between them while, the other treatments were less effective in this concern. The highest value of anthocyanins content was obtained from untreated control. These results were achieved in the two seasons and were in agreement with those obtained by Perez et al. (1999), Aday et al. (2014) and Kannaujia et al. (2019).

Table 7: Effect of ozone treatments on anthocyanins $(\mathrm{mg} / 100 \mathrm{~g} \mathrm{~F} \mathrm{W)} \mathrm{of} \mathrm{strawberry} \mathrm{fruits} \mathrm{during} \mathrm{storage}$ at $0^{\circ} \mathrm{C}$ in 2017 and 2018 seasons.

\begin{tabular}{|c|c|c|c|c|c|c|c|c|c|}
\hline \multicolumn{10}{|c|}{ Storage period (days) } \\
\hline $\begin{array}{c}\text { Treatments } \\
\text { (min) }\end{array}$ & $\mathbf{0}$ & 3 & 6 & 9 & 12 & 15 & 18 & 21 & Mean \\
\hline & & & & 2017 & & & & & \\
\hline Control & $78.68 \mathrm{~g}$ & $79.23 \mathrm{~g}$ & $81.32 \mathrm{~d}-\mathrm{g}$ & $83.26 \mathrm{c}-\mathrm{f}$ & $84.15 \mathrm{~cd}$ & $85.92 \mathrm{bc}$ & $88.32 \mathrm{~b}$ & $97.60 \mathrm{a}$ & $84.81 \mathrm{~A}$ \\
\hline 10 & 78.6 & $78.86 \mathrm{~g}$ & $79.13 \mathrm{~g}$ & $79.57 \mathrm{~g}$ & $79.91 \mathrm{f}-\mathrm{g}$ & $80.24 \mathrm{e}-\mathrm{g}$ & $81.13 \mathrm{~d}-\mathrm{g}$ & $83.35 \mathrm{c}-\mathrm{f}$ & $80.11 \mathrm{C}$ \\
\hline 20 & $78.68 \mathrm{~g}$ & $78.83 \mathrm{~g}$ & $78.95 \mathrm{~g}$ & $79.17 \mathrm{~g}$ & $79.32 \mathrm{~g}$ & $79.68 \mathrm{~g}$ & $79.93 \mathrm{fg}$ & $81.11 \mathrm{~d}-\mathrm{g}$ & $79.46 \mathrm{E}$ \\
\hline 30 & $78.68 \mathrm{~g}$ & 78.7 & $78.83 \mathrm{~g}$ & $78.95 \mathrm{~g}$ & $79.13 \mathrm{~g}$ & $79.34 \mathrm{~g}$ & $79.56 \mathrm{e}-\mathrm{g}$ & & $9.15 \mathrm{~F}$ \\
\hline 40 & $78.68 \mathrm{~g}$ & $78.86 \mathrm{~g}$ & $78.97 \mathrm{~g}$ & $79.21 \mathrm{~g}$ & $79.38 \mathrm{~g}$ & $79.71 \mathrm{~g}$ & $79.97 \mathrm{fg}$ & $81.34 \mathrm{~d}-\mathrm{g}$ & $79.51 \mathrm{D}$ \\
\hline 50 & $78.68 \mathrm{~g}$ & $78.93 \mathrm{~g}$ & $79.22 \mathrm{~g}$ & $79.65 \mathrm{e}-\mathrm{g}$ & $79.96 \mathrm{fg}$ & $80.43 \mathrm{e}-\mathrm{g}$ & $81.63 \mathrm{~d}-\mathrm{g}$ & $83.57 \mathrm{c}-\mathrm{e}$ & $80.26 \mathrm{~B}$ \\
\hline Mean & $78.68 \mathrm{H}$ & $78.91 \mathrm{G}$ & $79.40 \mathrm{~F}$ & $79.97 \mathrm{E}$ & $80.31 \mathrm{D}$ & $80.89 \mathrm{C}$ & $81.75 \mathrm{~B}$ & $84.49 \mathrm{~A}$ & \\
\hline \multicolumn{10}{|c|}{2018} \\
\hline Contrs & $78.32 \mathrm{j}$ & $79.21 \mathrm{~h}-\mathrm{j}$ & e-i80.94 & e-g81.72 & $83.84 \mathrm{cb}$ & $\mathrm{bc} 8$ & & & $84.02 \mathrm{~A}$ \\
\hline 10 & $78.32 \mathrm{j}$ & $78.62 \mathrm{j}$ & $78.90 \mathrm{ij}$ & $79.04 \mathrm{~h}-\mathrm{j}$ & $79.31 \mathrm{~h}-\mathrm{j}$ & g-j79.66 & g-j80.12 & $82.42 \mathrm{ef}$ & $79.55 \mathrm{C}$ \\
\hline 20 & $78.32 \mathrm{j}$ & $78.51 \mathrm{j}$ & $78.61 \mathrm{j}$ & $78.87 \mathrm{ij}$ & $79.15 \mathrm{~h}-\mathrm{j}$ & $79.29 \mathrm{~h}-\mathrm{j}$ & $79.73 \mathrm{~g}-\mathrm{j}$ & $80.87 \mathrm{e}-\mathrm{i}$ & $79.17 \mathrm{E}$ \\
\hline 30 & $78.32 \mathrm{j}$ & $78.39 j$ & $78.45 j$ & $78.53 \mathrm{j}$ & $78.75 \mathrm{ij}$ & $78.95 \mathrm{~h}-\mathrm{j}$ & $79.12 \mathrm{~h}-\mathrm{j}$ & g-j79.76 & $78.78 \mathrm{~F}$ \\
\hline 40 & $78.32 \mathrm{j}$ & $78.54 \mathrm{j}$ & $78.65 \mathrm{j}$ & $78.96 \mathrm{~h}-\mathrm{j}$ & 79.26h-j & $79.47 \mathrm{~h}-\mathrm{j}$ & $79.87 \mathrm{~g}-\mathrm{j}$ & $81.13 \mathrm{e}-\mathrm{h}$ & $79.27 \mathrm{D}$ \\
\hline 50 & $78.32 \mathrm{j}$ & $78.64 j$ & $78.95 \mathrm{~h}-\mathrm{j}$ & $79.22 \mathrm{~h}-\mathrm{j}$ & $79.52 \mathrm{~g}-\mathrm{j}$ & $79.75 \mathrm{~g}-\mathrm{j}$ & $80.22 \mathrm{f}-\mathrm{j}$ & $82.63 \mathrm{de}$ & $79.65 \mathrm{~B}$ \\
\hline Mean & $78.32 \mathrm{H}$ & $78.65 \mathrm{G}$ & $79.08 \mathrm{~F}$ & $79.39 \mathrm{E}$ & $79.97 \mathrm{D}$ & $80.40 \mathrm{C}$ & $80.89 \mathrm{~B}$ & $83.89 \mathrm{~A}$ & \\
\hline
\end{tabular}

Means in the same column having the same letter are not significantly different at 0.05 level by Duncan's multiple rang test.

In general, the interaction between postharvest treatments and storage periods was significant effect on anthocyanins content in the two seasons. After 21 days of storage at $0^{\circ} \mathrm{C}$, the lowest values of anthocyanins content were recorded from all ozone treatments of strawberry fruits while the highest ones were obtained from untreated control. 


\section{Total sugars:}

Data in Table (8) revealed that total sugars content of strawberry fruits were significantly affected by storage period. There was a significant reduction in total sugars by the prolongation of storage period in both seasons. These results were in agreement with those obtained by Castro et al. (2002) and Atala (2015) on strawberry fruits. The decrease of total sugars content is probably due to the consumption of sugars through respiration (Wills et al., 1981).

Table 8: Effect of ozone treatments on total sugar $(\mathrm{mg} / 100 \mathrm{~g} \mathrm{~F} \mathrm{W)} \mathrm{of} \mathrm{strawberry} \mathrm{fruits} \mathrm{during} \mathrm{storage}$ at $0^{\circ} \mathrm{C}$ in 2017 and 2018 seasons.

\begin{tabular}{cccccccccc}
\hline & & \multicolumn{1}{c}{ Storage period (days) } \\
\hline Treatments(min) & $\mathbf{0}$ & $\mathbf{3}$ & $\mathbf{6}$ & $\mathbf{9}$ & $\mathbf{1 2}$ & $\mathbf{1 5}$ & $\mathbf{1 8}$ & $\mathbf{2 1}$ & Mean \\
\hline & & & & $\mathbf{2 0 1 7}$ & & & & & \\
Control & $5.63 \mathrm{a}$ & $5.06 \mathrm{~d}-\mathrm{g}$ & $4.431 \mathrm{~m}$ & $3.80 \mathrm{op}$ & $3.43 \mathrm{r}$ & $2.93 \mathrm{~s}$ & $2.26 \mathrm{t}$ & $1.33 \mathrm{u}$ & $3.61 \mathrm{D}$ \\
$\mathbf{1 0}$ & $5.63 \mathrm{a}$ & $5.40 \mathrm{a}-\mathrm{c}$ & $5.06 \mathrm{~d}-\mathrm{g}$ & $4.76 \mathrm{~g}-\mathrm{k}$ & $4.431 \mathrm{~m}$ & $3.96 \mathrm{no}$ & $3.76 \mathrm{oq}$ & $3.46 \mathrm{q}-\mathrm{r}$ & $4.56 \mathrm{C}$ \\
$\mathbf{2 0}$ & $5.63 \mathrm{a}$ & $5.53 \mathrm{ab}$ & $5.40 \mathrm{a}-\mathrm{c}$ & $5.13 \mathrm{c}-\mathrm{f}$ & $4.96 \mathrm{e}-\mathrm{i}$ & $4.83 \mathrm{f}-\mathrm{j}$ & $4.60 \mathrm{j}-1$ & $4.06 \mathrm{no}$ & $5.02 \mathrm{~B}$ \\
$\mathbf{3 0}$ & $5.63 \mathrm{a}$ & $5.56 \mathrm{a}$ & $5.50 \mathrm{ab}$ & $5.46 \mathrm{a}-\mathrm{b}$ & $5.23 \mathrm{~b}-\mathrm{e}$ & $5.06 \mathrm{~d}-\mathrm{g}$ & $4.96 \mathrm{e}-\mathrm{i}$ & $4.56 \mathrm{jm}$ & $5.25 \mathrm{~A}$ \\
$\mathbf{4 0}$ & $5.63 \mathrm{a}$ & $5.50 \mathrm{ab}$ & $5.33 \mathrm{a}-\mathrm{d}$ & $5.06 \mathrm{~d}-\mathrm{g}$ & $4.93 \mathrm{e}-\mathrm{i}$ & $4.73 \mathrm{~h}-1$ & $4.50 \mathrm{~km}$ & $3.90 \mathrm{op}$ & $4.95 \mathrm{~B}$ \\
$\mathbf{5 0}$ & $5.63 \mathrm{a}$ & $5.33 \mathrm{a}-\mathrm{d}$ & $5.03 \mathrm{~d}-\mathrm{h}$ & $4.70 \mathrm{i}-\mathrm{l}$ & $4.26 \mathrm{mn}$ & $3.90 \mathrm{op}$ & $3.60 \mathrm{pr}$ & $3.36 \mathrm{r}$ & $4.47 \mathrm{C}$ \\
Mean & $5.63 \mathrm{~A}$ & $5.40 \mathrm{~B}$ & $5.12 \mathrm{C}$ & $4.82 \mathrm{D}$ & $4.54 \mathrm{E}$ & $4.23 \mathrm{~F}$ & $3.95 \mathrm{G}$ & $3.45 \mathrm{H}$ & \\
\hline & & & & $\mathbf{2 0 1 8}$ & & & & & \\
Control & $5.83 \mathrm{a}$ & $5.13 \mathrm{~g}-\mathrm{j}$ & $4.601-\mathrm{n}$ & $4.10 \mathrm{o}-\mathrm{q}$ & $3.56 \mathrm{r}$ & $3.06 \mathrm{~s}$ & $2.40 \mathrm{t}$ & $1.50 \mathrm{u}$ & $3.77 \mathrm{D}$ \\
$\mathbf{1 0}$ & $5.83 \mathrm{a}$ & $5.56 \mathrm{a}-\mathrm{e}$ & $5.30 \mathrm{~d}-\mathrm{g}$ & $4.96 \mathrm{~h}-\mathrm{k}$ & $4.76 \mathrm{k}-\mathrm{m}$ & $4.43 \mathrm{~m}-\mathrm{o}$ & $4.06 \mathrm{pq}$ & $3.60 \mathrm{r}$ & $4.81 \mathrm{C}$ \\
$\mathbf{2 0}$ & $5.83 \mathrm{a}$ & $5.66 \mathrm{a}-\mathrm{c}$ & $5.50 \mathrm{a}-\mathrm{f}$ & $5.26 \mathrm{e}-\mathrm{h}$ & $5.16 \mathrm{~g}-\mathrm{j}$ & $4.93 \mathrm{~h}-1$ & $4.73 \mathrm{k}-\mathrm{m}$ & $4.33 \mathrm{n}-\mathrm{p}$ & $5.17 \mathrm{~B}$ \\
$\mathbf{3 0}$ & $5.83 \mathrm{a}$ & $5.70 \mathrm{ab}$ & $5.66 \mathrm{a}-\mathrm{c}$ & $5.60 \mathrm{a}-\mathrm{d}$ & $5.50 \mathrm{a}-\mathrm{f}$ & $5.36 \mathrm{c}-\mathrm{g}$ & $5.16 \mathrm{~g}-\mathrm{j}$ & $4.96 \mathrm{~h}-\mathrm{k}$ & $5.47 \mathrm{~A}$ \\
$\mathbf{4 0}$ & $5.83 \mathrm{a}$ & $5.63 \mathrm{a}-\mathrm{d}$ & $5.43 \mathrm{~b}-\mathrm{g}$ & $5.20 \mathrm{f}-\mathrm{i}$ & $5.10 \mathrm{~g}-\mathrm{j}$ & $4.86 \mathrm{j}-1$ & $4-60 \mathrm{l}-\mathrm{n}$ & $4.16 \mathrm{o}-\mathrm{q}$ & $5.10 \mathrm{~B}$ \\
$\mathbf{5 0}$ & $5.83 \mathrm{a}$ & $5.43 \mathrm{~b}-\mathrm{g}$ & $5.26 \mathrm{e}-\mathrm{h}$ & $4.90 \mathrm{i}-1$ & $4.66 \mathrm{k}-\mathrm{n}$ & $4.36 \mathrm{n}-\mathrm{p}$ & $3.96 \mathrm{q}$ & $3.53 \mathrm{r}$ & $4.74 \mathrm{C}$ \\
Mean & $5.83 \mathrm{~A}$ & $5.52 \mathrm{~B}$ & $5.29 \mathrm{C}$ & $5.00 \mathrm{D}$ & $4.79 \mathrm{E}$ & $4.50 \mathrm{~F}$ & $4.15 \mathrm{G}$ & $3.68 \mathrm{H}$ & \\
\hline
\end{tabular}

Means in the same column having the same letter are not significantly different at 0.05 level by Duncan's multiple rang test.

Concerning the effect of postharvest treatments, data revealed that there were significant differences between all ozone treatments and untreated control in total sugars content of strawberry fruits during storage. Strawberry fruits which exposed to ozone gas for $30 \mathrm{~min}$. retained more total sugars content, followed by ozone treatments for 20 and $40 \mathrm{~min}$. with no significant differences between them in the two seasons. However, ozone treatments for 10 and 50 min. were less effective in this concern. The lowest value of total sugars content was obtained from untreated control. These results were achieved in the two seasons and were in agreement with those obtained by Perez et al. (1999), Aday et al. (2014) and Kannaujia et al. (2019).

In general, the interaction between postharvest treatments and storage periods was significant effect on total sugars content in the two seasons. After 21 days of storage at $0^{\circ} \mathrm{C}$, strawberry fruits treated with all ozone treatments had the highest values of total sugars content as compared with untreated control, which gave the lowest values at the same period.

\section{Conclusion}

From the previous results, it could be conclude that strawberry fruits which exposed to ozone gas for $30 \mathrm{~min}$. was the most effective treatment in maintaining fruit quality, it would reduce weight loss percentage and gave fruits without decay and maintaining fruit firmness, TSS, ascorbic acid content, anthocyanins content and total sugars and gave fruits with good appearance after 21 days of storage at $0^{\circ} \mathrm{C}$ and $95 \% \mathrm{RH}$.

\section{References}

Aday, M. S., M. B. Buyukcan, R. Temizkan and C. Caner, 2014. Role of ozone concentrations and exposure times in extending shelf life of strawberry. Science \& Engineering, 36: 43-56.

Ali, A., M. Abrar, M.T. Sultan, A. Din and B. Niaz, 2011. Post-harvest physicochemical changes in full ripe strawberries during cold storage. J. Animal Plant Sci., 21(1):38-41. 
Almenar, E., V. Del Valle, P. Hernández-Munoz, J. M. Lagaron, R. Catala and R. Gavara, 2007. Equilibrium modified atmosphere packaging of wild strawberries. J. Sci. Food Agri., 87:19311939.

An, J., M. Zhang and Q. Lu, 2006. Effects of pretreated ozone and modified atmosphere packaging on the quality of fresh-cut green asparagus. Int. Agrophysics, 20:113-119.

A.O.A.C., 1990 Quality of Official Analytical Chemists, Washington DC. USA.

Atala, S.A., 2015. Physiological studies on strawberry. Ph.D. Thesis, Fac., Agric., Cairo Univ., Egypt, $156 \mathrm{p}$.

Atress, A. S. H. and M. M. Attia, 2011. Effect of 1- methylcyclopropene and hot water treatments on retarding ripeness of cantaloupe fruits during cold storage. Egypt. J. Agric. Res., 89(3): 10891103.

Castro, I., O. Goncalves, J. A. Teixeira and A. A. Vicentesc, 2002. "Comparative study of Selva and Camarosa strawberries for the commercial market". Journal of Food Science, 67 (6): 2132-2137.

Coelho, C. C.S., O. F. Silva, R. S. Campos, M. S.G. Pereira and L. M. C. Cabral, 2014. Effect of aqueous ozone to control fungal postharvest diseases of strawberry. Blucher Food Science Proceedings, 1(1):485- 486.

Costa, L., A.R. Vicente, P.M. Civello, A. Chaves and G.A. Martinez, 2006. UV-C and ozone treatment delays postharvest senescence in broccoli florets. Postharvest Biol. Technol., 39:204-210.

FDA. Pesticide Program, Residue Monitoring, 1998; US Food and Drug Administration: Washington, D.C., 1999.

Guzel-Seydim, Z. B., A. K.Greene and A. C. Seydim, 2004. Use of ozone in the food industry. LWTFood Science and Technology, 37(4): 453-460.

Han, C., C. Lederer, M. Mcdaniel and Y. Zhao, 2005. Sensory evaluation of fresh strawberries (Fragaria ananassa) coated with chitosan-based edible coatings. Journal of Food Science, 70:172 $-178$.

Jaksch, D., R. Margesin, T. Mikoviny, J.D. Skalny, E. Hartungen, F. Schinner, N.J. Mason and T.D. Mark, 2004. The effect of ozone treatment on the microbial contamination of pork meat measured by detecting the emissions using PTR-MS and by enumeration of microorganisms. Int. J. Mass Spectrom., 239:209-214.

Kader, A. A., L.L. Morris and E.C. Maxie, 1973. Systems for scoring quality of harvested lettuce. Hort. Sci., 8:408-409.

Kalt, W. and J. E. McDonald, 1996. "Chemical composition of lowbush blueberry cultivars". Journal of the American Society for Horticultural Science, 121 (1): 142-146.

Kannaujia, P. K., R. Asrey, A. K. Singh, E. Varghese and K. Bhatia, 2019. Influence of ozone treatment on postharvest quality of stored summer squash. Indian J. of Hort., 76(2): 350-354.

karaca, H. and Y. S. Velioglu, 2007. Ozone applications in fruit and vegetable processing. Food Reviews International, 23:91-106.

Kim, T. J., J. L. Silva, A. Tokitkla and F. B. Matta, 2010. "Modified atmosphere storage influences quality parameters and shelf life of 'tiflue' blueberries". Journal of the Mississippi Academy of Science, 4 (55):143-148.

Koh, T.H. and L.D. Melton, 2004. Ripening-related changes in cell wall polysaccharides of strawberry cortical and pith tissues. Postharvest Biology and Technology, 26: 23-33.

Kuchi, V. S. and C.S. R. Sharavani, 2019. Fruit Physiology and Postharvest Management of strawberry. DOI: 10.5772, 20 pages. http://dx.doi.org/10.5772/ intechopen.84205.

Lee, S. K. and A. A. Kader, 2000. "Pre-harvest and postharvest factors influencing vitamin C content of horticultural crops". Postharvest Biology and Technology, 20 (3): 207-220.

Malik, C. P. and M. B. Singh, 1980. Plant enzymology and histo- enzymology: A text Manual Kalyani Publications, New Delhi/ Ludhiana, pp. 434.

Mishra, R. and A. Kar, 2014. Effect of storage on the physicochemical and flavour attributes of two cultivars of strawberry cultivated in northern India. Scientific World Journal, Article ID 794926, 7 pages. http://dx.doi.org/10.1155/2014/794926.

Morais, M.L., J. E. O. Alvinhao, D. V. Franco, E. de B. Silva and N. A. V. D. Pinto, 2015. Application of ozone aiming to keep the quality of strawberries using a low cost reactor. Rev. Bras. Frutic. Jaboticabal - SP, 37 (3): 559-567. 
Mshraky, A. M., 2017. The impact of some innocuous treatments (UV, Ozone, anise oil and acetic acid) on maintaining the quality attributes of "Swelling" peach fruit at cold storage. Inter. J. Chem. Tech. Research, 10(2):332-344.

Nogata, Y., H. Ohta and A.G.V. Voragen, 1993. Polygalacturonase in strawberry fruit. Phytochemistry, 34: 617-620.

Osman, K. A., 2015. Production of date palm fruits free of acaricides residues by ozone technology as post-harvest treatment. J. Food Sci. Technol., 52(6):3322-3335.

Palou, L., J. Smilanick and D. Margosan, 2007. Ozone applications for sanitation and control of postharvest diseases of fresh fruits and vegetables. In book: Recent Advances in Alternative Postharvest Technologies to Control Fungal Diseases in Fruits and Vegetables, pp. 39-70.

Perez, A. G., C. Sanz, J.J. Rios, R. Olias and J.M. Olias, 1999. Effects of ozone treatment on postharvest strawberry quality. J. Agric. Food Chem., 47: 1652-1656.

Sadasivam, S. and A. Manickam, 2004. Biochemical Methods, $2^{\text {nd }}$ edition, New Age International (P) Ltd, Publishers, New Delhi.

Shalluf, M.A., C. Tizaoui and N. Karodia, 2007. Controlled atmosphere storage technique using ozone for delay ripening and extend the shelf life of tomato fruit. IOA Conference and Exhibition Valencia, Spain, 7 p.

Skog, L. J. and C.L. Chu, 2001. Effect of ozone on qualities of fruits and vegetables in cold storage. Canadian Journal of Plant Science, 81(5):773-778.

Snedecor, G. W. and W.G. Cochran, 1980. Statistical methods. $7^{\text {th }}$ Edition Iowa State Univ. Press. Ames. Iowa, USA.

Souza, L. P., L. R. D. Faroni, F. F. Heleno, P. R. Cecon, T. D. C. Goncalves, G. J. Silva and L. H. F. Prates, 2018. Effects of ozone treatment on postharvest carrot quality. LWT- Food Science and Technology, 90: 53-60.

Stolfa, I., S. Marik, S. Marik, A. Stanisavljevic, R. Vukovic, D. Spoljaric and M. Varga, 2014. The impact of environmentally friendly postharvest treatments on the antioxidant activity of strawberry fruits during storage. Poljoprivreda, 20: (2)23-28.

Suslow, T., 1998. Basics of ozone applications for postharvest treatment of fruits and vegetables. Perishables Handling Quarterly, 94: 9- 11.

Suslow, T.V., 2004 .Ozone applications for postharvest disinfection of edible horticultural crops. UC Agriculture \& Natural Resources Postharvest, DOI:10.3733/ucanr.8133, 8 pages.

Thaer, Y., A. M. D'Onghia and A. Riccelli, 2013. The use of ozone in strawberry post-harvest conservation. Biological Control of Fungal and Bacterial Plant Pathogens, IOBC-WPRS Bulletin 86: 143-148.

Waller, R. A. and D. B. Duncan, 1969. A Buyes rule for the symmetric multiple comparison problems. Amer. State. Assoc. J., 64:1484-1503.

Wills, R. B. H., T. H. Lee, D. Grahum, W. B. McGlasson and E. G. Hall, 1981. Postharvest, an introduction to physiology and handling of fruits and vegetables. Inc. Westport, Connectiut, USA.

Wills, R., B. Mc Glasson, D. Graham and D. Joyce, 1998. Postharvest: An introduction to the physiology and Handling of fruit, vegetables and ornamentals (4th end n). CAB international, New York, pp: 77-96.

Zhang, X., Z. Zhang, L. Wang, Z. Zhang, J. Li and C. Zhao, 2011. Impact of ozone on quality of strawberry during cold storage. Frontiers of Agriculture in China, 5(3): 356-360. 